\title{
The Production and Destruction of Forests through the Lens of Landesque Capital Accumulation
}

\author{
Lowe Börjeson ${ }^{1}$ (D) Tola Gemechu Ango ${ }^{2,3}$ \\ Accepted: 9 February 2021 / Published online: 4 May 2021 \\ (C) The Author(s) 2021
}

\begin{abstract}
We discuss the management of trees and forests through the lens of "landesque capital." A theoretical point of departure is how landesque capital accumulates through a process that relies on both the 'work of nature' and the 'work of people.' This approach highlights the importance of undertaking a critical analysis of labor investment and its landscape legacies in relation to ecological processes, social dynamics, and political economy. Empirically we draw on the case of smallholder production of coffee and annual crops in southwestern Ethiopia. We show how both the production (generation and maintenance) and destruction of forests in the study area are largely shaped by processes of landesque capital accumulation and discuss the importance of analyzing how people contribute to produce forests to meet production goals in contrast to the ubiquitous notion of humans as a solely destructive force of change in forest ecosystems.
\end{abstract}

Keywords Landesque capital $\cdot$ Hybrid labor $\cdot$ Forest management $\cdot$ Coffee production $\cdot$ Ethiopia

\section{Introduction}

The main thread running through this special issue is the question of how useful and relevant it is to conceptualize nonprimary forests simply as secondary growth forests. The critique is that the category of secondary forest is too sweeping and unclear and does not reflect a reality where most if not all forested and wooded landscapes are the result of purposeful management to produce goods such as timber, food, fiber, and fuel for human consumption. Forest management may also generate other values (or ecosystem services) such as carbon storage and biodiversity conservation, as well as values for a diversity of cultural and recreational uses. While as a land use category forests are the focus of much of current global conservation efforts, most forests and woodlands are the result of management practices undertaken for the production and

Lowe Börjeson

lowe.borjeson@humangeo.su.se

1 Department of Human Geography, Stockholm University, 106 91 Stockholm, Sweden

2 Department of Human Geography, Stockholm University, 106 91 Stockholm, Sweden

3 Department of International Environment and Development Studies, Norwegian University of Life Sciences, 1430 Ås, Norway harvesting of goods. Forests are landscapes that over long periods have been purposefully managed by humans (Balée et al. 2020; Hecht et al. 2014). One implication of this is that naturalizing concepts such as "secondary growth," "re-generation," or "human disturbance," which suggest that normal forest dynamics are the same as ecological processes (i.e., not social-ecological), ignore the co-constitution of forests through social and natural processes (cf. Hecht et al. 2014). Indeed, the basic assumption underlying the notion of secondary growth or a secondary forest is that it has regenerated from a previous disturbance (such as a partial or wholesale removal or destruction of trees). Hence, it is a concept that places emphasis on nature's capacity to restore forests after disturbance.

For obvious reasons, human induced disturbances are often at the center of forest change analysis, even if events like wildfire or storm felling may occur naturally. However, the term "secondary" does not capture those disturbances that are of a more continuous character. These include those that aim to maintain or improve the capacity of forests to yield specific goods - e.g., through practices of planting and selective removal or protection of specific trees or species - which in the long-run may work to sustain forests. Such forest would be in a permanent secondary stage. If forest management strategies are designed to intervene and alter forest ecologies, the concepts of "secondary growth" or "regeneration" basically cease to carry meaning. A more useful starting point is to approach 
forests as "working landscapes" (Hecht et al. 2014), "taskscapes" (Ingold 1993), or similar notions that emphasize the legacy of human work processes in shaping them. Therefore, in contrast to the well-established discourse of forest and biodiversity, degradation, and conservation we also need to address the generative work of people in producing forests. It should also be noted here that production and harvesting of goods are often done in parallel with conservation efforts (as the same forest can be subject to both regulations aimed at protecting biodiversity and practices of harvesting goods). Furthermore, the same land use practice, such as for example the maintenance of shade trees for coffee production, may contribute simultaneously to both production and conservation goals so that it is important to consider these processes together.

We discuss the conceptualization of forest and wooded landscapes that are managed primarily to support the harvesting of goods through the analytical lens of landesque capital. We argue that a terminology that takes human production of forests (i.e., forest growth that is substantially moderated by purposeful practices) as the point of departure opens analytically useful avenues for debating forest dynamics in the Anthropocene (cf. Head 2016). Further, the workshop from which this special issue is drawn was to "review what we know about smallholders' active forest regeneration management practices and investments in the landscape, drawing on and developing the notion of landesque capital" (Pain et al. 2020).

We first review the literature on landesque capital, specifically "green" landesque capital. We then draw on the case of smallholder coffee production in southwestern Ethiopia as an example of how trees and forests can be conceptualized and operationalized as forms of landesque capital.

\section{What Is Landesque Capital and how Can it Be of Interest to the Study of Forest Dynamics?}

In their analysis of the political ecology of land degradation, Blaikie and Brookfield (1987: 7) argued that humans not only degrade landscapes through their management, but also help create productive ecosystems. The term they used to capture such processes was landesque capital, and as Börjeson (2014) has argued the concept basically denotes the antithesis to degraded land. Landesque capital usually refers to physical features, which can be referred to as "brown" (i.e., the movement and improvement of soils) or "grey" (i.e., the movement of stones) landesque capital, typically constituting drainage ditches, terraces, irrigation structures, stone walls, ridges, anthropogenic soils, etc. As Widgren and Håkansson (2014) note, landesque capital is frequently used as a shorthand for the most conspicuous types of 'brown' and 'grey' landesque capital, including irrigation systems, drainage works, and terracing (for a recent example see Sheehan et al. 2018). This also reflects how the concept has mainly been used in land change studies (e.g., Turner and Fischer-Kowalski 2010).

A problem with using the term as a synonym for a few specific types of structures or enduring qualities associated with specific farming systems is that it ends up being rhetorically practical rather than theoretically grounded. According to Börjeson (2014), this separation between a theoretical (based on Blaikie and Brookfield 1987) and an empirical (i.e., as a synonym for specific enduring landscape structures) definition is conceptually unsatisfactory, and indicates the need to provide clarity as to what landesque capital is, what it is not, and what it adds in terms of analytical focus (Widgren and Håkansson 2014), as for example in a discussion of forest dynamics. In particular, "green" landesque capital (accumulated through the management of vegetation), compared with "brown" and "grey" landesque capital, remains poorly conceptualized and empirically uncertain (cf. Brookfield 2001, 2007) and thus merits more attention.

As Morrison (2014) discussed, the obscurity of both the terms "landesque" and "capital" contribute to why the concept has received only marginal attention in mainstream humanenvironment and landscape change research. But as she points out, the concept clearly highlights an important facet of sustainability challenges, agrarian production, and humanenvironment dynamics (cf. Widgren and Håkansson 2014):

One major contribution of the concept of landesque capital is its emphasis on the ways producers, even those from the distant past or using strategies sometimes disdained as simple or primitive, often created enduring value in specific landscapes, improving the potential of those places for production over the long run. In this sense, the concept draws attention to the 'embodied histories' of productive landscapes, the very specific forms of interaction between human and nonhuman actors that have, in many cases, created new and enhanced possibilities for agrarian productivity. (Morrison 2014: 49)

The main analytical potential of thinking about processes of landesque capital accumulation, we argue, lies in the inherent juxtaposition of acts of conservation vs. production. While landesque capital is a concept that articulates the productive qualities, or capabilities, of agrarian landscapes for the purpose of producing material goods, i.e., crops, wood, fiber, livestock etc. that rely on photosynthesis and the active moderation of ecosystems, conservation (of ecosystems and biodiversity) revolves around concerns of limiting degradation and improving intactness (or health) of ecosystems. A key insight here, though, is that this does not necessarily imply a positive relation between accumulation of landesque capital and degradation. Nor does it imply the reverse, a positive relation between landesque capital and improved biodiversity 
and ecosystem health. Any investment in landesque capital will moderate local ecosystem functions, and may enhance some, while degrading others. The point is that we can (and as we argue below, should) both conceptualize human labor as work that needs to be regulated (for conservation purposes) and as work that contributes to producing ecosystems, or specific ecosystem features, for purposes of harvesting goods for human consumption. In neither case is there a need to place human labor outside the realm of ecosystems. On the contrary, the usefulness of this juxtaposition is that it allows for the focus to shift between viewing the same landscape through a lens of conservation and a lens of production, without jumping between ontological positions (e.g., as would be the case if a forest is viewed as nature vs socio-nature). By paying attention to the fact that labor is not only invested for the purpose of destruction, but also for enhancing productive capacities of landscapes we gain a richer analytical vantage point, compared to conceptual framings that primarily focus on conservation through an analysis of human disturbance to and from which the ecosystem responds and recovers.

A key question related to the accumulation of landesque capital in land-based production systems is how to value the contribution of "the work of nature" (ecological processes), and whether this contribution can be realized as a form of value that reaches beyond merely use values (cf. Kallis and Swyngedouw 2018). This question is beyond the scope of this paper, but we stress the importance of questioning whether landesque capital represents a form of capital that is defined by its resistance to alienation (being inseparable from its embeddedness in local context), quantification, and capture by market exchange, or whether landesque capital may indeed represent capital also in capitalist relations of production (Widgren and Håkansson 2014). A tentative answer here is that this may vary depending on the intensity with which such relations incorporate a specific form of landesque capital. ${ }^{1}$

Previous attempts to integrate the concept of landesque capital with analyses of land systems and ecosystem dynamics, including the modeling of land system changes, have regarded it as an emergent property of land systems seen to moderate ecosystem processes in ways that may lead to both path dependence and the rapid transformation of land systems (Chowdhury and Turner 2006; Geoghegan et al. 1998; Holling and Sanderson 1996; Turner and Shajaat Ali 1996; Turner and Fischer-Kowalski 2010). These attempts provide examples of how the concept may be integrated with mainstream land systems research and with integrative framings of coupled human and natural systems. In relation to the allencompassing framing of the earth's lands, waters, and biodiversity as natural capital (Ehrlich et al. 2012), the concept of landesque capital represents not only a different ontological

\footnotetext{
${ }^{1}$ This issue is debated by several of the contributors in the edited volume by Håkansson and Widgren (2014).
}

perspective, but also an opportunity to articulate how biophysical and societal processes interact to enhance land capability. In a recent critique of both the economic accounting of ecological functions as natural capital (or ecosystem services) and positions that resist economic valuation of ecological work, Battistoni (2017) proposed that the 'work of nature' should indeed be incorporated in political economy analyses, not as a basis for economic accounting but to focus attention on morethan-human politics. As she proposes:

The concept of hybrid labor articulates a view of nature that neither reduces it to a set of objects to be instrumentally used by humans nor arbitrarily declares elements of it to be inviolable. It insists that nature cannot be left out of politics and economics, yet does not capitulate to purely economic logic; nor does it uphold the sharp distinction of human and nonhuman drawn in classical political economy. Instead, in recognizing nature as a site of lively more-than human actors rather than as a resource or backdrop for human activity, it offers a view of a potential politics - an impetus to think in terms of solidarity across species." (2017: 25)

As a strategy to acknowledge the importance of both human and "natural forces" in shaping the qualities of land, Blaikie and Brookfield deliberately avoided using the term "value." Instead they argued that the process of land degradation represents a loss of intrinsic qualities of the land, which they conceptualized as a reduction in the capability to satisfy a particular landuse or production purpose (Blaikie and Brookfield 1987: 6). While we contend that the fundamental rationale of defining landesque capital must in the same way be concerned with the accretion of intrinsic productive quality or capacity of landscapes (in specific relational contexts), this does not preclude the symbolic, political, religious, and cultural dimensions that are also integral to many processes of landesque capital formation (Sheridan 2014). In fact, it is important to avoid reducing the concept to a quantitative measure of capital in agrarian production (cf. Morrison 2014). From this we can conclude that the process of landesque capital accumulation could also be framed as a form of hybrid labor if understood as a process that places emphasis on the political economy of co-working humans and non-humans.

The most cited and used definition of landesque capital is: "any investment in land with an anticipated life well beyond that of the present crop, or crop cycle" (Blaikie and Brookfield 1987: 9). The two critical aspects here are 1) the enduring nature of the investment, i.e., appearing as a form of capital related to the accumulated work (including skills) spent, and 2) that it is for the benefit of future, rather than current, production. The reference to "capital" emphasizes that it is an investment that is not spent during the production process, but that is an enduring feature of a production landscape that 
benefits a specific production goal, e.g., an irrigation canal, and that it remains as capital over multiple harvest seasons.

Even if planted and managed trees can be regarded as enduring modifications in landscapes, we may need to differentiate between trees as landesque capital and trees as other forms of capital (e.g., natural capital). If a tree is planted or managed for the sole function of being harvested, e.g., as timber, it has the same function as a crop and does not have "an anticipated life well beyond that of the present crop..." and hence, represents an investment in a product (wood) not in the land to improve conditions for production. But, in all situations where fruits, leaves, sap, branches etc. are harvested, the trees are indeed landesque capital. Trees that are planted and managed for the sole purpose of sequestering carbon would, however, not be landesque capital, as the capital (the tree) here is the same as the product (the carbon stock). In other words, the value a plant or any configuration of vegetation has as landesque capital must be different from its value as a harvested product or the products harvested from it. This means that landesque capital is defined in relation to how it benefits the production of something else, which can be any type of land-based production purpose, e.g., to produce material goods such as crops, wood, fiber, livestock, etc. In many cases, however, such as agroforestry systems, trees may have value both as landesque capital (for other crops produced in the system) and as a resource to be harvested (wood).

In sum, the essence of any form of landesque capital is 1) the prior spending and embeddedness of human work ${ }^{2}$ and 2) its function as a physical modification of a terrestrial ecosystem (land) that is beneficial for a specific production purpose and that lasts beyond the point where the value of that production is realized, e.g., through harvesting. However, while landesque capital was introduced by Blaikie and Brookfield as a concept to distinguish investments or management practices that are purposively made "to secure future production" from seasonal land management that are intended only for the production of "the current crop" (1987: 9), this distinction is not always easy to draw. As Börjeson (2014) has discussed, research on landesque capital, including that by Doolittle (1984), Brookfield (2001, 2007), Cairns and Brookfield (2011), Davies (2014), and Ferro-Vázquez et al. (2017), has clearly shown the importance of incremental changes to landscapes and how routine work processes can over time lead to substantial accumulation of landesque capital. Hence, the emphasis on what is purposive (or not) must also allow for analyses of slow incremental change, including modifications of vegetation patterns and plant diversity.

One way to operationalize the concept of landesque capital for analysis of empirical contexts where types and amounts of accumulated landesque capital vary is to take Blaikie and

\footnotetext{
${ }^{2}$ In the same fashion, Bourdieu points at "accumulated labor" as being the fundament of capital (1986: 241).
}

Brookfield (1987) argument and their "land degradation equation" and reverse it to instead define intensity of landesque capital investments. Thus:

Landesque capital intensity $=$ (investments [i.e., physical human work] + biophysical interference) - (natural degrading processes + destructive management) (Börjeson 2014)

However, this equation to clarify landesque capital as a relation between the work of people and the work of nature does not make it clear how to distinguish landesque capital from any other form of investment in land. The statement of "any" investments is rather sweeping and does not offer much guidance. The clue here lies in the term "landesque," which refers to a feature (a form of capital as discussed above) of the land that resembles the land itself, but is produced by human modification of the local terrain and ecology. A strict interpretation implies that the concept can only be applied to features considered to be inseparable from the land itself both materially and conceptually, i.e., something that looks like and is perceived of as an inherent quality or part of the land itself. Any form of building or construction that is primarily viewed as separated from the land (as a terrestrial ecosystem) in a symbolic or material way, is thus not a form of landesque capital. What counts as landesque is thus a perceptual category, which implies that distinctions between what is viewed as landesque or not is a relationally constructed rather than materially determined categorization (cf. Widgren and Håkansson 2014). However, we propose that one useful and important material and analytical distinction, based on the interpretation of "landesque" as a feature that resembles the land itself, is that structures built from material sourced from other locations, or by labor spent elsewhere, would not qualify as "landesque." The definition of landesque capital would then be reserved for investments in land that are based on the moderation of ecosystems by primarily locally spent labor and by using primarily locally available natural resources. The articulation of this distinction is also reflected in how the concept has typically been used by scholars (Håkansson and Widgren 2014). It is also analogous to the way that land degradation and degraded land is viewed as an intrinsic quality and inseparable from the land itself, i.e., a process concerned with human modification and use of ecosystems and natural resources at the site where degradation takes place. Such a definition would not speak to "any" investment, but to a specific type of investment in land-based production systems that relies on the on-site input of human work and the use and moderation of local material and ecological processes that increase land's capability for a specific production purpose. Hence, we propose turning the obscurity of the term "landesque" into a practical operational definition that centers 
on the accumulation of productive capital through in-situ work, e.g., by local communities (human and other species), and the use of material sourced from the local terrestrial ecosystem. This definition would be indifferent to the movement of people (as labor) across landscapes, what matters is where the work is carried out. On the other hand, it would build on a strict definition as a spatially fixed and locally produced form of capital, implying that materials sourced from other sites would not count as landesque.

Adding this operational definition, we believe, also provides a necessary foundation to explore green landesque capital and more generally allow for a move away from an empirically centered use of the concept as a shorthand for a few specific types of agricultural landscapes (e.g., irrigated and terraced). We propose that a positive response to the following questions can be used to establish if a specific landscape feature can be defined as landesque capital or not (cf. Widgren and Håkansson 2014), even if we also recognize that the perceptual conception of what is regarded as landesque or not also resists an unequivocal objective delineation of the concept:

1. Is the landscape feature spatially fixed and immovable?

2. Is the landscape feature an intrinsic quality of the land, both materially and symbolically, i.e., not primarily positioned as separate from the qualities of the land itself?

3. Is the landscape feature improving conditions for future production, i.e., lasting for multiple harvesting events?

4. Is the landscape feature dependent on the prior input of human physical work in-situ?

5. Is the landscape feature consisting of in-situ available natural material, stationary living organisms, or both?

We now return to the issue of forests or trees as a form of landesque capital and the importance of assessing how human actions may not only degrade and conserve forest, but also generate forests for specific production purposes. In the Sahelian parklands (and indeed any other type of agroforestry landscape) trees provide important landesque capital. One interesting aspect of these parklands is that the long history (Höhn and Neumann 2012) of managing a moderate density of trees has been shown to improve groundwater availability in an optimal way. An increased density of trees would consume more water from the ground, while a lower density of trees would reduce rates of water infiltration (Ilstedt et al. 2016). Hence, these extensive areas of agroforestry parklands moderate the local ecology to improve the conditions for growing crops, grazing livestock, and harvest fuelwood, leaves and other tree products, in an enduring way.

We also note the insights that the cases of Nepal and Peru, discussed by Pain et al. (2021) in this issue, provide about the importance of trees as landesque capital. In the Nepal case the use of trees as sources of fodder has supported a transition to more intensive stall-fed livestock production as well as providing increased opportunities for commercial extraction of non-timber forest products outside protected forest areas. This accumulation of landesque capital has in effect contributed to the production of a new type of managed forest mosaic landscape in the region, reversing a previous trend of clearing forests for agricultural expansion. The driving forces involved in this transformation, such as regulations of forest use, migration, and remittances from global labor markets, have contributed to devalue the landesque capital represented by cleared land, while increasing the value of trees and forested landscapes as landesque capital in local land-based production. In the Peru case, green landesque capital is produced in relation to swidden farming and agroforestry-based cash crop production. In particular, the two cases highlight the transition zone between landscapes dominated by forestry regulations (e.g., for REDD+ and conservation goals) and agricultural livelihoods as key to study the forces of production and destruction of forests in relation to local livelihood dynamics and political-economic contexts. These reveal the potential synergies between biodiversity conservation and rural development. Both cases point to the importance of understanding landesque capital accumulation in relation to social processes, such as migration, social differentiation, and generation of non-farm income. Hence, accumulation of green landesque capital is part of a wider circulation of capital as well as related to other forms of investments in landscapes for a diversity of production goals. Investigations into such relations may thus provide insights about how landesque capital accumulation is part of differentiated household economies, changing land use strategies, agricultural intensification, global and regional capital circulation, and migration processes.

\section{Processes of Accumulation and Destruction of Landesque Capital in Southwestern Ethiopia's Mountainous Forests}

We build on recent research investigating the multiple factors and processes that have shaped forest cover and produced an agriculture-forest mosaic landscape in southwestern Ethiopia through an analysis of smallholders' coffee production, topography, migration, population dynamics, and state policies. An outcome highlighted by this research is the importance of assessing both activities that maintain forests as well as drivers of deforestation and the linkages between them (Ango et al. 2020). This point aligns with our argument that shifting between a conservation and production lens is a means to decenter the dominant discourse on destructive human practices. A comprehensive basis for devising biodiversity conservation and forest landscape management policies must also recognize human production of forests and build on analyses of 'embodied histories' of productive landscapes. We aim to 
show how key forms of green landesque capital may be identified in a specific landscape and how landesque capital investments shape trajectories of change by examining how the dynamics and variation in landesque capital accumulation and degrading forces have produced the specific forest mosaic landscape of southwestern Ethiopia.

\section{The Forest Mosaic Landscape of Gera District}

Most of Ethiopia's remaining forests are in the southwest and offer favorable conditions for coffee (Coffea arabica) production (Senbeta 2006). The forest coffee and semi-forest coffee ecosystems (Gole et al. 2002), including those in the southeast, contribute about $45 \%$ of coffee produced in the country (Kufa 2012). Coffee is also Ethiopia's main source of foreign currency (FDRE 2012). Shaded and home garden coffee, even when intermixed with other land uses, have also been shown to support biodiversity, as reflected in, for example, epiphyte and bird diversity (Hylander and Nemomissa 2008; Rodrigues et al. 2018). Despite an overall deforestation trend in the region and the country as a whole, ${ }^{3}$ smallholders use of shade trees, e.g., Albizia gummifera, Acacia abyssinica, and Millettia ferruginea, for coffee production has been shown to have a clear conserving effect on forest cover within coffee-growing altitudes, c. 1300-2000 m (Getahun et al. 2013; Hylander et al. 2013).

Our research is focused on the Gera district, Jimma zone, Oromia region. The district has a total area of $1454 \mathrm{~km}^{2} \mathrm{di}-$ vided into 29 rural kebeles and a town, and about 138,000 inhabitants, $95 \%$ of whom are smallholder farmers (CSAg 2013). Altitudes range between 1390 and 2980 m.a.s.l. Coffee is an important income source for most smallholding farmers in the district. Each kebele is classified as located either within a coffee growing area or highland area largely on the basis of the microclimatic suitability for shade coffee production, following differences in altitude (Ango et al. 2020).

In addition to coffee, the southwest moist evergreen Afromontane forests shelter several tree species, including Olea welwitschii, Pouteria adolfi-friedericii, Schefflera abyssinica, and Syzygium guineense (Friis et al. 2010), as well as other economically important endemic plant species such as the spice Aframomum corrorima (Senbeta 2006). The forest is also widely used for honey production using locallyproduced beehives hung on trees (Ango 2018).

Consistent with previous findings for southwestern Ethiopia (Hylander et al. 2013), Gera district also has lower rates of deforestation in coffee areas $(14.4 \%$ of the total forest cover lost) than in highland areas $(74.2 \%$ of the total forest cover lost) over the period 1973-2010 (Ango et al. 2020).

\footnotetext{
$\overline{3}$ Between 1990 and 2015 the forest area in Ethiopia decreased by $0.8 \%$ per year, from 15.1 to 12.5 million ha (FAO 2015)
}

Interestingly, the most rapid loss of forest occurred between 1973 and 1985 and 2001-2010 in both coffee and highland areas, as well as in state forest sites demarcated as protected forests. These periods coincide with the implementations of major state policies and programs related to agricultural development and forest conservation. These policies, both during the socialist Derg rule and the post-1991 'free marketoriented' federal rule, had unintended consequences that resulted in increased deforestation. The greatest decrease in forest cover occurred in highland areas, and in the more recent period has also been linked to a population increase from internal migration from both coffee growing and other highland areas, and a subsequent expansion of crop cultivation. In addition to shade for coffee production, increased domestic and market demand for wood products had contributed to an expansion of tree-planting, e.g., woodlots of mainly eucalyptus, so that two coffee growing areas (Sadi Loya and Wanja Kersa) gained forest cover from 1995 to 2010 . These eucalyptus plantations, along with other trees managed in the landscape for various purposes such as shade and fencing (Ango et al. 2014), are potential sources of wood for farmers that ease pressure on nearby forest.

Thus, ecological variation, commercial production by smallholder farmers, internal migration, and policy interventions have contributed to produce the forest mosaic landscape. We find two basic forms of landesque capital in the Gera mosaic landscape: 1) areas cleared from forests to support annual crop production, and 2) planted and selectively retained and managed shade trees providing more or less dense forest/tree cover to support coffee production. The investment and expansion of eucalyptus woodlots do not represent an obvious form of landesque capital, as the main purpose here is to harvest the trees to sell or use as timber. It would, however, be possible to identify other forms of landesque capital in the region, such as live fences, improved soils, and various forms of earthworks, but for the purpose of this paper we will focus on the two basic forms: shade trees and land cleared from forest.

\section{Landesque Capital Accumulation in the Gera Landscape}

In line with the definition presented above single, smaller stands, or large expanses of shade trees constitute landesque capital for the purpose of coffee production. Gole et al. (2002) have classified coffee production systems into four categories: the forest ecosystem, semi-forest coffee system, garden coffee and plantation coffee systems. Forest, semi-managed forest, and garden coffee systems are managed by a diversity of farmers, mainly smallholders, and account for $95 \%$ (gardens contribute nearly 50\%) of the coffee produced in Ethiopia. The remainder is plantation coffee managed by state or private investors (Ango 2018). Despite basic differences in terms of the coffee varieties used and the organization and 
Table 1 Landesque capital intensity in Gera's production landscapes resulting from different combinations of human and ecosystem work. Work input and resulting landesque capital intensity is approximated as none, low or high input/intensity

\begin{tabular}{llll}
\hline Type of landscape & $\begin{array}{l}\text { Landesque capital } \\
\text { intensity }\end{array}$ & $\begin{array}{l}\text { Nature's contribution to } \\
\text { landesque capital }\end{array}$ & $\begin{array}{l}\text { Humans contribution to } \\
\text { landesque capital }\end{array}$ \\
\hline $\begin{array}{c}\text { Old growth forest } \\
\text { with coffee }\end{array}$ & Low/none & High & Low/none \\
$\begin{array}{c}\text { Managed coffee } \\
\text { forest }\end{array}$ & High & High & High \\
$\begin{array}{c}\text { Coffee plantations } \\
\text { and gardens }\end{array}$ & High & Low & High \\
$\begin{array}{c}\text { Land cleared for } \\
\text { cultivation }\end{array}$ & High & None & High \\
\hline
\end{tabular}

management of production between garden and plantation coffee, these two systems support a similar number of trees species, canopy cover, and number of canopy cover tree species (Gole 2015: 14, Table 1). Overall, the shade trees in both garden and plantation systems are partly retained from naturally grown trees and partly planted, although the proportions of planted and retained trees can vary from place to place. For reasons of simplicity, we here combine these into a category of "coffee plantations and gardens" as both represent more labor-intensive systems than the forest and semi-forest coffee systems. We use the intensity gradient of shade coffee production following Gole: 1) extensive harvesting of semi-wild coffee by smallholders in old grown forest ecosystems (forest coffee), 2) smallholder coffee production in managed forests (semi-forest coffee system), and 3) coffee plantations and smallholder coffee gardens.

The first category is old growth mountain forest landscape (see Fig. 1 in Pain et al. 2020). Even if coffee is harvested from old growth mountain forests, the legacy of labor investment for the purpose of increasing the capacity of coffee production is low or insignificant. As Gole (2015) reports, labor is mainly invested in creating paths to reach the coffee, suggesting that landesque capital intensity in the form of shade trees is also low. The second category is relatively dense and managed forest produced through smallholders' engagement in coffee production (cf. "successional forest" in Fig. 1 ibid.). Here we assume that farmers' management (selective removal and protection of trees) over time has improved the productive capacity of the forest for coffee production, so the landesque capital intensity is relatively high and has accumulated through a combination of ecological processes and human labor. The third category is an intensively managed garden or plantation system with less diversity of tree species and lower density of tree cover. Assuming at least part of the coffee crop in these systems is established on cleared forest land, the clearing and subsequent planting or retaining and management of shade trees both represent landesque capital. The difference in this category compared to the managed coffee forest is that ecological processes have contributed less to the accumulation of landesque capital, while the legacy of labor input means that landesque capital intensity is also high.
Finally, we address land cleared for the purpose of annual crop cultivation. As with garden and plantation coffee production, there is a legacy of human labor investments made to clear the forest and prepare the land for cultivation, but here we assume that there was no biophysical interference 'assisting' with the clearing and preparation (Table 1).

Thus, the amount of accumulated landesque capital is primarily linked to legacies of labor investments, even if the contribution of ecosystem functions may also have significant effects on accumulation processes. A landscape with high landesque capital intensity implies that previous labor investments are a strong structuring feature in that landscape, representing either costs or benefits for any change or continuity in type of land use and management. Also, the landscapes with higher biodiversity and conservation values (the old growth forest and the managed coffee forests) are those associated with a high ecosystem contribution to landesque capital. Basically, these are the landscapes generally regarded as forests, as the impact of human labor is less conspicuous compared to coffee plantations, gardens, or cleared land. It is useful to contrast the managed coffee forest and the coffee plantation. While the labor invested in the plantation is obvious (the removal of the forest), the labor invested in maintaining shade trees (forest) as landesque capital is often not so clear. In fact, the more we identify this partly human-made capital (shade trees) as forest, the more we risk expunging the legacy of human labor investment, management skills, and knowledge, from this landscape. Thus an analysis of landesque capital, by revealing legacies of labor that may otherwise remain conceptually and analytically obscured, necessitates a perspective that accommodate both human production of forests and human destruction of forests. If, for example, drawing on social-ecological principles or frameworks we address how biodiversity conservation can be reconciled with local interests in land based production and landscape management, as for example in agro-forestry systems and crop production in mosaic landscapes (Ango et al. 2014; Fischer et al. 2017), landesque capital provides a lens to analyze legacies of labor-ecosystem relations and their impact on change trajectories. It is precisely this landscape moderation effect, we argue, that is the key rationale for studying the 
relational dynamics of landesque capital accumulation vis-àvis processes of land degradation. To conclude, an analysis of landesque capital directs questions both to the investments made in landesque capital (e.g., the social and economic relations of labor mobilization) and the constraining effect it has on land change trajectories.

\section{Processes of Spatial Differentiation and Destruction of Landesque Capital in the Gera Landscape}

As described above, the forest mosaic landscape of Gera has been shaped by three main forces: 1) smallholder's commercial coffee production and annual crop cultivation, 2) policy interventions to promote agricultural development and improve forest management (e.g., participatory forest management), and 3) migration dynamics (Ango et al. 2020) that have resulted in a clearly differentiated topographical pattern related to the altitudinal reach of coffee. The areas above the coffee growing zone, except in the most inaccessible, and steep slopes (which are largely protected as state forests) have been deforested and cleared for annual crop cultivation. Open agricultural land also dominates below the coffee growing zone, while the mid-range altitudes where coffee can grow are largely covered with managed coffee forest. Across these landscapes, smallholders have also invested in eucalyptus woodlots for commercial timber production and to compensate for lack of access to forests. This altitudinal differentiation of agricultural production has been reinforced by internal migration and social-economic relations between zones. For example, many farmers who maintain forest for shade coffee and honey production in coffee areas are also involved in internal migration and forest conversion in highland areas. Forest conservation in the coffee areas and forest conversion in the highland areas are thus linked processes. Cases of deforestation displacement, as a result of strict conservation, have been reported from other areas (e.g., Ingalls et al. 2018; Meyfroidt and Lambin 2009). In Gera, however, deforestation displacement has been largely driven by local farmers' decisions and practices to use forest ecosystem services across the landscape (i.e., shade coffee production) and to avoid related 'disservices' (e.g., wild mammal pests). In effect, these relationally linked processes of smallholder landscape investments (in shade coffee and annual crop cultivation) reveal a distinct geographic pattern and differentiation between landesque capital maintained for coffee production (shade tree forest) and for annual crop cultivation (e.g., land cleared for cultivation and live fences) (Ango et al. 2014). In other words, the pattern of forest cover in this landscape can largely be explained through the mechanism of purposeful investments in landesque capital. This also implies that the conceptual lens of conservation is inadequate for explaining why large parts of the Gera landscape remain forested, as it is predominantly smallholders' investments in shade trees as landesque capital for commercial coffee production (through co-work with ecosystem processes) that has produced the forests.

Thus far, we have mainly addressed the investment and accumulation of landesque capital, i.e., how, for example, deforestation produces landesque capital for annual crop cultivation and how management of shade trees accumulates landesque capital for coffee cultivation. But, as the value of this landesque capital is linked to the specific production purposes, a shift in production focus, e.g., change of crop, may fundamentally alter how landscape configurations are valued as landesque capital or as obstacles impeding production potentials. We illustrate this with two scenarios: climate change and crop price change.

With change towards a warmer climate the coffee growing zone will shift towards higher elevations (Ovalle-Rivera et al. 2015). At lower elevations, where coffee can no longer be grown productively, shade trees will consequently cease to be valued as landesque capital, while an expansion of new managed shade tree forest may be expected at higher elevations that are now dominated by open agricultural land. Hypothetically, the extent of managed coffee forests may also change following the relative returns of coffee vs. annual crop production for example. If coffee farmers in Gera, due to dramatic changes in commodity prices, find it more rewarding and secure to cultivate annual crops, shade trees will no longer have the same value as landesque capital (cf. McCann 1995). In such a scenario, shade trees may thus shift from being valued as landesque capital for coffee production to being valued as timber, which may result in increased rates of deforestation of previous shade coffee forests. The same argument can be used to illustrate the problem of maintaining trees as landesque capital in other types of agroforestry systems. If land managers, for example, find it more beneficial to shift to mechanized annual crop production, they may purposefully invest labor in clearing trees from the land.

\section{Forest Dynamics through the Lens of Landesque Capital}

To highlight the diversity of forests types that are commonly referred to as secondary forests, the conceptual model presented by Pain et al. (2020) in this issue charts out a diversity of disturbance, management, and successional processes that shape forest landscapes, illustrating the need for more nuanced framings of forests dynamics than the crude division between primary and secondary forests offers. We add to this schema by making a distinction between production vs. conservation goals and by locating processes of landesque capital investment in relation to the different forest management processes.

Pain et al. (ibid.) sort forest change processes along a gradient from agricultural land and logged forests to 'successional forests' to 'old growth forests.' If we add a distinction between 'production goals' and 'conservation goals' we find that 
Table 2 Forest/tree management processes represented in the conceptual model by Pain et al. (2020), this issue, and their relation to conservation vs production goals and nature's vs. humans contributions to landesque capital accumulation

\begin{tabular}{lllll}
\hline Management process & $\begin{array}{l}\text { Main activity/work task (1.e., } \\
\text { planting trees, removing trees } \\
\text { or a diversity of tree } \\
\text { management practices) }\end{array}$ & Primarygoal & $\begin{array}{l}\text { Nature's } \\
\text { contribution } \\
\text { to landesque } \\
\text { capital }\end{array}$ & $\begin{array}{l}\text { Humans } \\
\text { contribution } \\
\text { to landesque } \\
\text { capital }\end{array}$ \\
\hline $\begin{array}{l}\text { Reforestation/Afforestation } \\
\text { Assisted regeneration }\end{array}$ & $\begin{array}{l}\text { Tree planting } \\
\text { Diverse tree management } \\
\text { practices }\end{array}$ & $\begin{array}{l}\text { Conservation } \\
\text { Conservation }\end{array}$ & None & None \\
Shifting agriculture & $\begin{array}{l}\text { Tree removal } \\
\text { Diverse tree management } \\
\text { practices }\end{array}$ & Production & Yes & None \\
Logged forestry & $\begin{array}{l}\text { Tree removal } \\
\text { Tree planting }\end{array}$ & Production & No & Yes \\
\hline
\end{tabular}

some processes represent restoration ('reforestation/afforestation' and 'assisted regeneration'), which are framed within an eco-centric perspective that expresses a clear conservation goal (i.e., the generation of more forests and more biodiversity rich forests). In contrast to this another set of processes that illustrate 'shifting agriculture', 'agroforestry', and 'logging and land conversion' primarily represent anthropogenic production goals. This distinction is naturally based on a simplification of these processes, where we associate 'restoration' with a process of planting trees to reverse deforestation and create new forest ecosystems or any form of vegetation management to support regeneration of forests ecosystems. Similarly, we associate the production-oriented management processes with tree planting for any production purpose, tree removal to clear land for cultivation, or other vegetation management for a production purpose (Table 2). We have not included 'Community/Social forestry' and 'Reduced Impact Logging' in Table 2 as these categories, in their diverse forms of intervention, do not represent either a clear conservation or production goal; we also note the contribution of nature and human work to landesque capital accumulation.

This simplified sorting of forest management practices into those with the primary aim to produce material goods for an economic purpose and those aimed at producing forests to fulfil conservation goals, illustrate that the lens of landesque capital can (based on its definition) be applied only to processes that are framed in relation to production concerns. Table 2 also illustrates how landesque capital is not associated with any specific type of tree management, as the same management action can be framed as either a concern with conservation or production, and most importantly that the accumulation of landesque capital is relationally defined as conditioned on physical labor invested to improve a specific enduring quality of the land for a specific production purpose. Hence, the same production-oriented management practice, e.g., tree planting and auxiliary vegetation management, may or may not contribute to the accumulation of trees or other vegetation managed as landesque capital, depending on its production purpose. However, it is important to note that as the purpose of both shifting cultivation and agroforestry is to produce crops and involves work processes intended to improve the conditions for future production seasons (e.g., clearing land for cultivation, enhancing soil quality, and tree planting/management), landesque capital is typically an intrinsic quality of both these landscapes.

\section{Conclusion}

We discuss the management of trees and forests through the lens of landesque capital to critique the common analytical tendency to naturalize forest growth by reducing the complexities of labor processes and their co-constitutive relations with ecological processes to the category of 'disturbance.' In the same way as a degraded landscape represents a destruction of value for a specific purpose, landesque capital represents an accumulation of productive value for a specific purpose. If the change in purpose, is, for example, due to a shift in commodity prices, technology, or regulation, prompting a shift or modification of the production system, any landesque capital may become devalued or even an obstacle (or cost) that burdens production (e.g., trees that are obstructing ploughing). This means that there may be diverging and conflicting perceptions of whether a landscape feature is regarded as a form of landesque capital or an obstacle that produces additional costs depending on the production purpose. The same process of landscape change (draining a wetland, clearing a patch of forest, etc.) will in most cases represent both degradation (e.g., in relation to conservation goals), and accumulation of landesque capital (e.g., in relation to a production goal). While this represents a common juxtaposition of degradation and production discourses, an analysis of landesque capital accumulation as an emergent property of land based production systems can be used as a tool to: 1) de-emphasize the work of humans as a destructive force in forest ecosystems, and 2) avoid expunging the legacy of human labor investment (including management skills and knowledge) through the use of naturalizing concepts such as 'secondary forests.' We show 
how an analysis of landesque capital, by revealing legacies of labor that may otherwise tend to remain conceptually and analytically obscured, necessitates a perspective that accommodates both human production of forests and human destruction of forests. Human degradation of forest ecosystems is a serious environmental problem, and how to reconcile conservation and production interests in land-based production systems is an overarching environmental governance challenge. An analysis of landesque capital directs questions towards both the investments made in production landscapes and the constraining effects on land change trajectories. Using the lens of landesque capital, we argue for the usefulness of placing analytical attention on legacies of laborecosystem relations, or 'hybrid labor,' and the purposeful production of forests by people co-working with ecosystem processes.

Funding Open access funding provided by Stockholm University. The work was made possible by a sabbatical grant awarded to Lowe Börjeson, funded by Stockholm University.

Declaration This is a conceptual paper that draws on empirical work published elsewhere. Hence, only secondary sources are referenced. No primary data on humans or animals are presented in the paper.

Conflict of Interest The authors declare they have no conflict of interest related to content presented in this paper.

Open Access This article is licensed under a Creative Commons Attribution 4.0 International License, which permits use, sharing, adaptation, distribution and reproduction in any medium or format, as long as you give appropriate credit to the original author(s) and the source, provide a link to the Creative Commons licence, and indicate if changes were made. The images or other third party material in this article are included in the article's Creative Commons licence, unless indicated otherwise in a credit line to the material. If material is not included in the article's Creative Commons licence and your intended use is not permitted by statutory regulation or exceeds the permitted use, you will need to obtain permission directly from the copyright holder. To view a copy of this licence, visit http://creativecommons.org/licenses/by/4.0/.

\section{References}

Ango, T.G. (2018). Medium-Scale" Forestland Grabbing in the Southwestern Highlands of Ethiopia: Impacts on Local Livelihoods and Forest Conservation. Land 7(1): 24. doi.org/10. 3390/land7010024

Ango, T.G., Börjeson, L., Senbeta, F., and Hylander, K. (2014). Balancing Ecosystem Services and Disservices: Smallholder Farmers' Use and Management of Forest and Trees in an Agricultural Landscape in Southwestern Ethiopia. Ecology and Society 19(1): 30. doi.org/10.5751/ES-06279-190130

Ango, T. G., Hylander, K., \& Börjeson, L. (2020). Processes of Forest Cover Change since 1958 in the Coffee-Producing Areas of Southwest Ethiopia. Land, 9(8): 278. https://doi.org/10.3390/ land 9080278
Balée, W., de Oliveira, V.H., dos Santos, R. et al. (2020). Ancient Transformation, Current Conservation: Traditional Forest Management on the Iriri River, Brazilian Amazonia. Human Ecology. doi-org.ezp.sub.su.se/https://doi.org/10.1007/s10745-02000139-3

Battistoni, A. (2017). Bringing in the work of nature: From natural capital to hybrid labor. Political Theory 45(1): 5-31. doi: https://doi.org/10. $1177 / 0090591716638389$

Blaikie, P., and Brookfield, H.C. (1987). Land Degradation and Society. London: Methuen.

Börjeson, L. (2014). "The antithesis of degraded land: toward a greener conceptualization of landesque capital". In Håkansson, N., and Widgren, M. (eds.). Landesque Capital. The Historical Ecology of Enduring Landscape Modifications. New York: Routledge. https:// doi.org/10.4324/9781315425696

Bourdieu, P. (1986). "The forms of capital". In J. Richardson (ed.) Handbook of Theory and Research for the Sociology of Education. New York: Greenwood, 241-258.

Brookfield, H.C. (2001). Intensification, and Alternative Approaches to Agricultural Change. Asia Pacific Viewpoint 42(2/3): 181-192.

Brookfield, H.C. (2007). "Working with and for Plants: Indigenous Fallow Management in Perspective". In Cairns, M. (ed.), Voices from the Forest: Integrating Indigenous Knowledge into Sustainable Upland Farming. Washington, DC: Resources for the Future.

Cairns, M., and Brookfield, H.C. (2011) Composite Farming Systems in an Era of Change: Nagaland, Northeast India. Asia Pacific Viewpoint 52(1): 56-84.

Chowdhury, R.R., and Turner, B.L.II. (2006). Reconciling Agency and Structure in Empirical Analysis: Smallholder Land Use in the Southern Yucatan, Mexico. Annals of the Association of American Geographers 96(2): 302-322.

CSAg. (2013). Population Projection of Ethiopia for All Regions at Wereda Level from 2014 - 2017. Central Statistical Agency, Addis Ababa, 118 pp. http://www.csa.gov.et/images/general/news/ pop_pro_wer_2014-\%0A2017_final Accessed: July 30, 2015.

Davies, Matthew I.J. (2014). "The Temporality of Landesque Capital: Cultivation and the Routines of Pokot Life". In Håkansson, N., and Widgren, M. (eds.). Landesque Capital. The Historical Ecology of Enduring Landscape Modifications. New York: Routledge. https://doi.org/10.4324/9781315425696

Doolittle, W.E. (1984). Agricultural Change as an Incremental Process. Annals of the Association of American Geographers 74(1): 124137.

Ehrlich, P.R., Kareiva, P.M., and Daily, G.C. (2012). Securing Natural Capital and Expanding Equity to Rescale Civilization. Nature 486(7401): 68-73.

FAO. (2015). Global Forest Resources Assessment 2015. Desk Reference. Rome.

FDRE. (2012). Coffee Opportunities in Ethiopia. Presentation of the Ministry of Trade. www.eafca.org/wwc/downloads/AFCCE09/ presentations/Coffee Accessed November 19, 2015.

Ferro-Vázquez, C., Lang, C., Kaal, J. and Stump, D. (2017). When is a terrace not a terrace? The importance of understanding landscape evolution in studies of terraced agriculture. Journal of Environmental Management 202: 500-513.

Fischer, J., Abson, D.J., Bergsten A., et al. (2017). Reframing the FoodBiodiversity Challenge. Trends in Ecology \& Evolution 32(5): 335345 .

Friis, I., Demissew, S., and van Breugel, P. (2010). The Atlas of Potential Vegetation of Ethiopia. Copenhagen: The Royal Danish Academy of Sciences and Letters.

Geoghegan, J., Pritchard, L., Ogneva-Himmelberger, Y., Chowdhury, R.R, Sanderson,S., and Turner, B.L.II. (1998). "'Socializing the Pixel' and 'Pixelizing the Social' in Land-Use and Land-Cover Change". In Liverman, D., Moran, E.F., Rindfuss, R.R and Stern, 
P.C. (eds.) People and Pixels: Linking Remote Sensing and Social Science. Washington, DC: National Academy Press.

Getahun, K., van Rompaey, A., van Turnhout P., and Poesen J. (2013). Factors Controlling Patterns of Deforestation in Moist Evergreen Afromontane Forests of Southwest Ethiopia. Forest Ecology and Management 304: 171-181. https://doi.org/10.1016/j.foreco.2013. 05.001 .

Gole, T. W. (2015). Coffee Production Systems in Ethiopia. Coffee: Ethiopia's Gift to the World - The traditional production systems as living examples of crop domestication, and sustainable production and an assessment of different certification schemes. Addis Abeba: Environment and Coffee Forest Forum (ECFF).

Gole, T.W., Denich, M., Teketay, D., Vlek, P.L.G. (2002). "Human impacts on the Coffea arabica genepool in Ethiopia and the need for its in situ conservation", in: Engels, J.M.M., Ramanatha Rao, V., Brown, A.H.D., Jackson, M.T. (eds.). Managing Plant Genetic Diversity. Wallington: CAB International, pp. 237-247.

Håkansson, N.T. and Widgren, M. (eds.) (2014). Landesque Capital. The Historical Ecology of Enduring Landscape Modifications. Routledge: New York. https://doi.org/10.4324/9781315425696

Head, L. (2016). Hope and Grief in the Anthropocene. Reconceptualising human-nature relations. Routledge: New York.

Hecht, S.B., Morrison, K.D. and Padoch, C. (eds.). (2014). The social lives of forests: past, present, and future of woodland resurgence. Chicago: University of Chicago Press.

Höhn, A., Neumann, K. (2012). Shifting cultivation and the development of a cultural landscape during the Iron Age $(0-1500 \mathrm{CE})$ in the Northern Sahel of Burkina Faso, West Africa: insights from archaeological charcoal. Quat. Int. 249: 72-83. https://doi.org/10.1016/j. quaint.2011.04.012.

Holling, C.S., and Sanderson, S. (1996). "Dynamics of (Dis)harmony in Ecological and Social Systems". In Hanna, S., Folke, C., and Mäler, K-G. (eds.), Rights to Nature: Ecological, Economic, Cultural, and Political Principles of Institutions for the Environment. Washington, DC: Island Press.

Hylander, K., and Nemomissa, S. (2008). Home Garden Coffee as a Repository of Epiphyte Biodiversity in Ethiopia. Frontiers in Ecology and the Environment 6(10): 524-528. https://doi.org/10. $1890 / 080001$

Hylander, K., Nemomissa, S., Delrue, J., and Enkosa, Woldeyohannes. (2013). Effects of Coffee Management on Deforestation Rates and Forest Integrity. Conservation Biology 27(5): 1031-1040. https:// doi.org/10.1111/cobi.12079.

Ilstedt, U., Bargués Tobella, A., Bazié, H. et al. (2016). Intermediate tree cover can maximize groundwater recharge in the seasonally dry tropics. Sci Rep 6(21930). https://doi.org/10.1038/srep21930

Ingalls, M.L., Meyfroidt, P., Xuan, T.P., Kenney-lazar, M., Epprecht, M. (2018). The transboundary displacement of deforestation under REDD + : Problematic intersections between the trade of forestrisk commodities and land grabbing in the Mekong region. Glob. Environ. Chang. 50: 255-267. https://doi.org/10.1016/j.gloenvcha. 2018.04.003

Ingold, T. (1993). The temporality of the landscape. World Archaeology 25(2): 152-174

Kallis, G. and Swyngedouw, E. (2018). Do bees produce value? A conversation between an ecological economist and a Marxist geographer. Capitalism Nature Socialism 29(3): 36-50.

Kufa, T. (2012). Recent Coffee Research Development in Ethiopia. In Presented at Ethiopian Coffee Export Conference: Strengthening the
Legacy of Our Coffee. Addis Ababa, Hilton. https://www. slideserve.com/dalton-rowland/recent-coffee-researchdevelopment-in-ethiopia-taye-kufa Accessed: December 14, 2017.

McCann, J.C. (1995). People of the Plow: An agricultural History of Ethiopia. Madison: University of Wisconsin Press.

Meyfroidt, P., Lambin, E.F. (2009). Forest transition in Vietnam and displacement of deforestation abroad. Proceedings of the National Academy of Sciences 106: 16139-16144. https://doi.org/10.1073/ pnas.0904942106

Morrison, K.D., (2014). "Capital-esque landscapes: long-term histories of enduring landscape modifications". In Håkansson, N., and Widgren, M. (eds.). Landesque Capital. The Historical Ecology of Enduring Landscape Modifications. New York: Routledge. https://doi.org/10. 4324/9781315425696

Ovalle-Rivera, O., Läderach P., Bunn, C, Obersteiner, M., and Schroth, G. (2015). Projected Shifts in Coffea Arabica Suitability among Major Global Producing Regions Due to Climate Change. PLoS ONE 10(4): 1-13.

Pain, A., Marquardt, K. and Khatri, D. (2021) Secondary Forests and agrarian transitions: insights from Nepal and Peru. Human Ecology. https://doi.org/10.1007/s10745-021-00224-1

Pain, A., Marquardt, K., Lindh, A. and Hasselquist, N.J. (2020). What is secondary about secondary tropical forest? Rethinking forest landscapes. Human Ecology. https://doi.org/10.1007/s10745-02000203-y

Rodrigues, P., Shumi G., Dorresteijn, I., et al. (2018). Coffee Management and the Conservation of Forest Bird Diversity in Southwestern Ethiopia. Biological Conservation 217: 131-139.

Senbeta, F. (2006). Biodiversity and Ecology of Afromontane Rainforest with Wild Coffea Arabica L. Populations in Ethiopia ( $\mathrm{PhD}$ Thesis). University of Bonn.

Sheehan, O., Watts, J., Gray, R.D., and Atkinson, Q.D. (2018). Coevolution of landesque capital intensive agriculture and sociopolitical hierarchy. Proceedings of the National Academy of Sciences, 115(14): 3628-3633.

Sheridan, M. (2014). "The Social Life of Landesque Capital and a Tanzanian Case Study”. In Håkansson, N., and Widgren, M. (eds.). Landesque Capital. The Historical Ecology of Enduring Landscape Modifications. New York: Routledge. https://oi.org/ 10.4324/9781315425696

Turner, B.L.II, and Fischer-Kowalski, M. (2010). Ester Boserup: An Interdisciplinary Visionary Relevant for Sustainability. Proceedings of the National Academy of Sciences 107(51): 21963-21965.

Turner, B.L.II., and Shajaat Ali, A.M. (1996) Induced Intensification: Agricultural Change in Bangladesh with Implications for Malthus and Boserup. Proceedings of the National Academy of Sciences 93: 14984-14991.

Widgren, M., and Håkansson, N.T. (2014). "Introduction. Landesque Capital: What is the Concept Good for?" In Håkansson, N., and Widgren, M. (eds.). Landesque Capital. The Historical Ecology of Enduring Landscape Modifications. New York: Routledge. https:// doi.org/10.4324/9781315425696

Publisher's Note Springer Nature remains neutral with regard to jurisdictional claims in published maps and institutional affiliations. 